\title{
SIEDMIOGRÓD WE WSPÓŁCZESNYM FILMIE WĘGIERSKIM. FIGURY (AUTO)KOLONIZACJI
}

\author{
ALEKSANDRA MUGA ${ }^{1}$ \\ (Uniwersytet im. Adama Mickiewicza w Poznaniu)
}

Słowa kluczowe: Siedmiogród, Trianon, film węgierski, postkolonializm

Key words: Transylvania, Trianon, Hungarian film, postcolonial studies

\begin{abstract}
Abstrakt: Aleksandra Muga, SIEDMIOGRÓD WE WSPÓŁCZESNYM FILMIE WĘGIERSKIM. FIGURY (AUTO)KOLONIZACJI. „PORÓWNANIA” 13, 2013, t. XIII, s. 179-189. ISSN 1733-165X. Po roku 1989 na Węgrzech odżyły wytłumione w czasach komunizmu resentymenty, będące spadkiem po historycznym okresie dominacji narodu węgierskiego nad terytorium Królestwa Węgier sprzed traktatu w Trianon. Eksplozja bolesnej, zbiorowej pamięci imperialnej Węgrów zaowocowała próbami symbolicznej, neokolonialnej restytucji utraconych ziem. Narodowe tęsknoty uwidoczniły się szczególnie jaskrawo w specyficznych, wartościujących przedstawieniach rumuńskiego Siedmiogrodu, chętnie eksplorowanego we współczesnym kinie węgierskim. Analiza najnowszych filmów usytuowanych w Transylwanii, ma na celu odsłonięcie środków wyrazu, służących mentalnemu upodrzędnieniu owego regionu.
\end{abstract}

Abstract: TRANSYLVANIA IN THE CONTEMPORARY HUNGARIAN CINEMATOGRAPHY. THE FIGURES OF (AUTO)COLONISATION. „PORÓWNANIA” 13, 2013, Vol. XIII, p. 179-189. ISSN 1733-165X. The Hungarian resentiments which were the result of the historic domination of the Hungarian nation over the territories of the Kingdom of Hungary before the treaty of Trianon, muted during the communist times, revived after 1989. The explosion of a painful collective memory of imperial Hungary resulted in symbolic neocolonial attempts at restoring the lost lands. The nostalgia is particularly visible in the valuative images of the Romanian Transylvania which is eagerly explored in the contemporary Hungarian cinema. The analysis of the newest films whose location was in Transylvania, is aimed at revealing the means of expression used to mentally objectify this region.

\footnotetext{
${ }^{1}$ Correspondence Address: olamuga@gmail.com
} 
Traktat pokojowy podpisany w 1920 roku w pałacu Grand Trianon w Wersalu pomiędzy Węgrami a państwami ententy, stanowi dla Węgrów do dziś żywe źródło traumy i powód, dla którego czują się w Europie najbardziej pokrzywdzonym przez historię narodem. Co roku 4 czerwca o godzinie 16.32 - bo o tej właśnie porze 93 lata temu oficjalnie przestały istnieć Wielkie Węgry, bicie dzwonów w wielu miejscach kraju przypomina o nieustającej żałobie z powodu utraty ponad dwóch trzecich terytorium i ponad połowy ludności, która po przesunięciu granic trafiła do ościennych państw. Węgierska opinia publiczna nie przyjęła do wiadomości oceny historyków i czołowych rodzimych myślicieli, takich jak Oszkár Jászi, László Németh, czy István Bibó, że Trianon był wynikiem nie tylko przegranej wojny, ale również organicznego, nieuniknionego procesu rozpadu wieloetnicznych państw Europy, którego siłą napędową stał się nowoczesny nacjonalizm, oparty na poczuciu wspólnoty językowo-kulturalnej². Etniczni Węgrzy stanowili przed I wojną światową mniej niż połowę mieszkańców Wielkich Węgier, ale to do nich należała prawie cała władza, którą wykorzystywali, aby urzeczywistniać utopijną ideę jednolitego "narodu politycznego" i, zgodnie z zasadą cuius regio eius natio, narzucać innym narodowościom swój język i kulturę, co powodowało narastający opór ${ }^{3}$.

Wytłumione $\mathrm{w}$ czasach komunizmu resentymenty, będące spadkiem po historycznym okresie dominacji narodu węgierskiego na terytorium Królestwa Węgier, odżyły po roku 1989. Popularne powiedzenie „Prawdziwym Węgrem jest ten, kogo boli Trianon" nie straciło do dziś aktualności. Aby się o tym przekonać, wystarczy zajrzeć do jednego z licznych sklepów, oferujących narodowe pamiątki najrozmaitsze przedmioty codziennego użytku ozdobione konturami Wielkich Węgier* . Węgierska melancholia - nieprzepracowana żałoba, stanowiąca istotny element tożsamości narodowej, bardzo przypomina polski stosunek do „kresów” wschodnich. „Każdy, kto wydaje tęskny głos w sprawie »kresów - pisał Bogusław Bakuła - jest prawdziwym Polakiem. Inni to właśnie wyłącznie Inni"5.

Eksplozja bolesnej, zbiorowej pamięci imperialnej Węgrów po 1989 roku zaowocowała próbami symbolicznej restytucji ziem utraconych również w sferze kultury artystycznej. Narodowe tęsknoty uwidoczniły się szczególnie jaskrawo w specyficznych, wartościujących filmowych przedstawieniach rumuńskiego Siedmiogrodu - największego z terenów utraconych w 1920 roku, przewyższającego powierzchnią obszar pozostawiony we władaniu Węgrów. Przedmiotem moich rozważań będą reprezentacje Transylwanii oraz innych partii Rumunii,

\footnotetext{
2 Zob. I. Romsics, Magyarország története a XX. században. Budapeszt 2005, s. 103.

${ }^{3}$ Zob. Ibidem, s. 84-88; J. Kochanowski, Wegry. Warszawa 1997, s. 33-35.

4 Przykładem mogą być sklepy internetowe: www.tataturul.lapunk.hu, www.nemzeti.bolt.hu. O podobnych miejscach w Budapeszcie pisał K. Varga w idem: Gulasz z turula. Wołowiec 2008, s. 93-98.

${ }^{5}$ B. Bakuła, Kolonialne i postkolonialne aspekty polskiego dyskursu kresoznawczego (zarys problematyki). „Teksty Drugie" 2006, nr 6, s. 15.
} 
zasiedlonych przez węgierskich bohaterów, w wybranych węgierskich filmach fabularnych ostatnich lat (w kolejności od, moim zdaniem, najbardziej wyrazistych przykładów dyskursu imperialnego) - Delta (Delta, 2008) Kornéla Mundruczó, Dallas Pashamende6 (2005) Róberta Pejó, Katalin Varga (Varga Katalin balladája, 2009) Petera Stricklanda7, Podróż Iszki (Iszka utazása, 2007) Csaby Bollóka i Bibliotheque Pascal (2010) Szabolcsa Hajdu. Analiza wymienionych filmów ma na celu wskazanie i omówienie środków wyrazu, służących mentalnemu upodrzędnieniu dawnych posiadłości.

\section{POCZĄTKI KOLONIALNEGO DYSKURSU FILMOWEGO NA WĘGRZECH}

Wspomniane filmy wyraźnie nawiązują do przerwanej przez epokę komunizmu tradycji kina międzywojennego. Choć do 1945 roku film fabularny na niewielką skalę podporządkowano państwowym celom propagandowym, każdy seans w kinie rozpoczynała kronika dokumentalna, której pierwsze ujęcia prezentowały rozczłonkowaną mapę Wielkich Węgier, przypominając o naczelnym imperatywie wszystkich międzywojennych rządów, jakim była rewizja postanowień traktatu.

Jedyny zachowany $\mathrm{w}$ całości film fabularny $\mathrm{z}$ tego okresu, poruszający problematykę Trianon - Ucichte dzwony (Elnémült harangok, 1941) László Kalmára, można uznać za wytwór myślenia kolonialnego. Jego tematem są relacje węgiersko-rumuńskie. Film zrealizowany tuż po drugim arbitrażu wiedeńskim, miał uzasadniać panowanie w tymczasowo odzyskanym Siedmiogrodzie. Fabuła przede wszystkim podkreśla ekstremalną przepaść cywilizacyjną dzielącą Rumunów od Węgrów. W autoportrecie Węgrów w filmie Kalmára naczelną rolę odgrywa solidarność narodu, oparta na przekonaniu o własnej wyższości kulturowej i historycznej dominacji - pierwotnej własności spornego terenu. Węgrzy są racjonalni, jednomyślni, heroiczni. Rumuni tkwią w średniowiecznym, zabobonnym świecie wierzeń. $\mathrm{W}$ dodatku ich szeregi pustoszy barbarzyńska walka klas. Znamienny jest dialog pomiędzy węgierskim pastorem a angielskim podróżnikiem, który pojawia się $\mathrm{w}$ filmie tylko po to, aby wziąć udział w tym jednym epizodzie. Wytworny obieżyświat ze zrozumieniem reaguje na wyczuwalną awersję Węgra wobec Rumunów, stwierdzając, że ich relacje przypominają stosunki pomiędzy kolonizatorami a autochtonami. Węgier natychmiast poprawia obcokrajowca, zaznaczając,

\footnotetext{
6 Tytuł filmu oznacza w języku Romów z okolic Végvár „Dallas obok nas”.

7 Peter Strickland jest z pochodzenia Brytyjczykiem. Wiele lat mieszkał na Węgrzech. Film Katalin Varga znalazł się $\mathrm{w}$ moim zestawieniu, ponieważ został zrealizowany $\mathrm{w}$ języku węgierskim, $\mathrm{z}$ węgierskim sztabem i siedmiogrodzkimi aktorami, w brytyjsko-rumuńsko-węgierskiej koprodukcji.
} 
że jego rodacy nie są dla Rumunów najeźdźcami, przynoszącymi zdobycze cywilizacji z zewnątrz, lecz rdzennymi mieszkańcami, którzy dzielą się owymi dobrami z rumuńskimi przybyszami.

Również po roku 1989 węgierski filmowy dyskurs imperialny będzie czerpał siłę z przekonania "to my byliśmy tutaj pierwsi”, z tą tylko różnicą, że główna rola subalterna, ofiary dyskursywnych represji, przypadnie węgierskim mieszkańcom Rumunii, a nie samym Rumunom, których obecność zostanie prawie całkiem wyrugowana z filmu. Dojdzie do swoistej (auto)kolonizacji jednych (peryferyjnych) Węgrów przez drugich (centralnych).

Reprezentacje Rumunii we współczesnym kinie węgierskim stanowią odpowiednik zachodniego wyobrażenia Orientu, opisanego przez Edwarda W. Saida swoisty mentalny wynalazek, przesycony uprzedzeniami i fantazjami ${ }^{8}$.Terytorium zamieszkałe przez Węgrów zza wschodniej granicy jawi się $w$ nich jako Inny węgierskości, przestrzeń dzika, surowa, zacofana, niemoralna, a jednocześnie egzotyczna, pełna wschodniego czaru, upragniona, pożądana, utracona. Warto przyjrzeć się bliżej językowi filmów, który zawiera w sobie te upośledzające wyobrażenia i ukrywa kolonialne struktury myślenia.

\section{CZASOPRZESTRZEŃ REZERWATU}

W węgierskich filmach o Rumunii w oczy rzuca się charakterystyczny dobór miejsc akcji. Wydarzenia $\mathrm{w}$ większości rozgrywają się $\mathrm{w}$ symbolicznych rezerwatach, w czasoprzestrzeni określanej przez Edwarda Saida „etnograficzną teraźniejszością" ${ }^{\prime \prime}$ - w miejscach nietkniętych cywilizacją, niezmiennych, rządzących się własnymi, odwiecznymi, zakonserwowanymi prawami. Zwykle jest to na poły mityczna, sfera natury, zmysłowo dzikiej przyrody - malownicze góry, lasy, delta Dunaju. Drugi biegun stanowi wysypisko śmieci w Dallas Pashamende - przedstawione jako środowisko życia węgierskich Romów w Rumunii, których nie obowiązują ogólnie przyjęte normy zachowań i dokąd „biały człowiek” zapuszcza się tylko z konieczności10. Fascynację węgierskich twórców Innościq, egzotycznością rumuńskich miejsc, widać $\mathrm{w}$ często stosowanych dalekich i ogólnych planach, mających na celu pełne ich pokazanie.

8 Zwróciła na to uwagę również M. Dánél, Kihordó természet, kultúra, nők - belső gyarmatok. Kortárs magyar filmek posztkoloniális olvasatai, „Metropolisz” 2011, nr 3.

9 Zob. B. Bakuła, op. cit., s. 19.

${ }^{10}$ Znamienne, że naturalistyczna sceneria śmietniska w Dallas... stała się zarzewiem międzynarodowego skandalu. Interwencja władz rumuńskich, niezadowolonych z wizerunku kraju, kreowanego w filmie, doprowadziła do skazania kierownika produkcji na karę więzienia $\mathrm{w}$ zawieszeniu i przymusowego przeniesienia planu zdjęciowego z Rumunii na Węgry. Zob. E. Boda Székedi, Filmajánló - Cigány világ, http://www.szekelyhon.ro/archivum/offline/cikk/22111/iv-evf-112-szam (data dostępu: 8.04.2013). 
Ważnym składnikiem tworzącym wyobrażoną czasoprzestrzeń Rumunii są odgłosy natury, zdradzające niekiedy nieproporcjonalnie większe zainteresowanie światem zwierząt niż ludzi, co było powszechnym zjawiskiem w hollywoodzkich filmach o Afryce ${ }^{11}$. Nieprzypadkowo film Katalin Varga został nagrodzony Srebrnym Niedźwiedziem na Festiwalu w Berlinie w 2009 roku za efekty dźwiękowe, nasuwające skojarzenia z filmami przyrodniczymi. Atmosferę świata przedstawionego $\mathrm{w}$ tym utworze $\mathrm{w}$ ogromnym stopniu budują autentycznie brzmiące odgłosy świerszczy i innych owadów, żab i ptaków. Z podobnym wykorzystaniem dźwięku mamy do czynienia w Delcie. Dzieło rozpoczyna scena przybycia głównego bohatera statkiem do miejscowości położonej w rumuńskiej Delcie Dunaju. Geograficzny region poznajemy $\mathrm{z}$ „perspektywy słyszenia” obcego. Określa go krzyk mew, muczenie krów, szczekanie psa, bzyczenie owadów, przedłużający się w nieskończoność kwik świni prowadzonej na rzeź, następnie cios, który go kończy i dopiero po dłuższym czasie pierwszy ludzki głos ${ }^{12}$. Ostatnie, ramowe ujęcie Delty należy z kolei do żółwia zmierzającego w kierunku rzeki. Milknie muzyka, słychać tylko szum wiatru i chlupot gada.

„Punkt słyszenia” kolonizatora ujawnia się również w innych kontekstach. Ella Shochat i Robert Stam zwrócili uwagę, że muzyka, dźwięki, stanowiące w kulturze rdzennych Amerykanów, Afrykanów czy Arabów rodzaj duchowej ekspresji, $\mathrm{w}$ kolonialnych filmach przygodowych zwykle prezentowane były jako lubieżne lub niebezpieczne, powodujące lęk, czy wrogość13. Analogicznie jawi się scena tańca, będąca bezpośrednią zapowiedzią zbrodni w Katalin Vardze - zabawa w rytm ludowej muzyki, na świeżym powietrzu, w krwisto czerwonym świetle ogniska, rozbudzająca w bohaterach dzikie, pierwotne żądze. W Delcie scena tańca w karczmie stanowi tło dla równie złowieszczych wydarzeń, potęgujących napięcie, które doprowadzi do tragedii.

\section{MORALNOŚĆ SUBALTERNA}

Do istoty miejsca w węgierskich filmach o Rumunii przypisane są różnego rodzaju zbrodnie i mroczne historie. Czasoprzestrzeń rumuńskiej „etnograficznej teraźniejszości" jawi się jako oczywista arena wydarzeń sprzed zakazu kulturowego - samosądów, morderstw, gwałtów, kazirodztwa. Nie ma filmu, w którym nie pojawiłby się przynajmniej jeden $\mathrm{z}$ tych motywów.

\footnotetext{
11 Zob. R. Stam, L. Spence, Colonialism, Racism and Representation. "Screen” 1983, nr 2, s. 7.

12 Zob. M. Dánél Mónika, Kihordó természet, kultúra, nök - belső gyarmatok. Kortárs magyar filmek posztkoloniális olvasatai, „Metropolisz” 2011, nr 3, s. 62.

${ }_{13}$ Zob. E. Shochat, R. Stam, Stereotype, Realism and the Struggle over Representation. In: Unthinking Eurocentrism. Multiculturalism and the Media. New York 1997, p. 209.
} 
Apogeum obrazowania mieszkańców Rumunii jako niemoralnych osiągnięto w Dallas... - portrecie węgierskich Romów lowarskich, głęboko przeszytym uprzedzeniami. Ich świat to przerysowana wizja plemiennej subkultury, żyjącej w skrajnej nędzy i odizolowaniu, gdzie człowiek ma znikome szanse na przeżycie. Bohaterowie filmu, mieszkańcy osady na wysypisku śmieci, stanowią ucieleśnienie najpowszechniejszych stereotypów antycygańskich. Są agresywni, nieokrzesani, prymitywni, niepiśmienni, nieodpowiedzialni, niezdolni do „normalnej” pracy. Nie dbają o dzieci, kradną, piją, zdradzają, oszukują, mordują. Są przy tym słabi zdani na łaskę policji i rodzimej mafii14.

W Delcie „barbarzyństwo” lokalnej węgierskiej społeczności zostało w interesujący sposób podkreślone poprzez intertekstualne odniesienie do filmu Recydywiści (Visszaesők, 1983) Zsolta Kézdi-Kovácsa. W obu utworach, opowiadających o kazirodczej miłości rodzeństwa, zagrała aktorka Lili Monori. Przy tym świat Kádárowskich Węgier w obrazie z lat 80 . okazał się bardziej prawy i humanitarny wobec społecznych wyrzutków. We współczesnej rumuńskiej Delcie Dunaju zamordowanych przez autochtonów ludzi wrzuca się do rzeki, przywracając ich naturze. Przesądy, pozwalające na przedstawienie węgierskich mieszkańców Rumunii jako niemoralnych lub egzotycznych, ujawniają się $w$ konstrukcji omawianych filmów nie tylko na poziomie fabuły. Zaprzęgnięto $w$ tym celu cały wyrafinowany aparat języka filmowego.

Do najciekawszych figur wykluczenia należą złożone metafory audiowizualne w Delcie. W jednej ze scen armada łodzi, wioząca tubylców, płynie na pogrzeb. Złowieszczo zbliża się do lądu, a potem odpływa przy dźwiękach muzyki z Nosferatu (1979) Wernera Herzoga. Sekwencja ta imituje popularny topos zachodnich filmów kolonialnych - przypomina atak dzikich plemion. Dodatkowo zbliżenie na nieme, wymowne twarze, $\mathrm{w}$ zestawieniu $\mathrm{z}$ sugestywnym komentarzem muzycznym, wiernie imitujące sekwencję otwierającą Nosferatu, wzbogaca scenę o ton paternalistyczny. Drakula w ujęciu Herzoga był wprawdzie krwiożerczym, nienasyconym siewcą zła, zarażającym ofiary swoimi wampirycznymi skłonnościami, ale przecież posiadał przy tym głęboko ludzką stronę. Pragnąc w głębi duszy miłości i akceptacji, boleśnie odczuwał swe krwawe napiętnowanie.

Innym filmowym sposobem na utrwalenie atawistycznego wizerunku mieszkańców Rumunii w omawianych utworach jest charakterystyczny wizualny leitmotiv - węgierski aktor z Siedmiogrodu, Tibor Pálffy, powracający w stereotypowych rolach brutala (Katalin Varga, Bibliotheque Pascal) lub wiejskiego wariata (Dallas Pashamende). E. Shochat i R. Stam pisali o ciężarze tego typu przedstawień $\mathrm{w}$ dyskursie hegemonistycznym. Wszystkie negatywne stereotypy są krzywdzące, ale nie wszystkie z jednakową mocą. Jeśli pejoratywny, uproszczony wizerunek

14 Zob. A. Örkény, Cigány film vagy Roma film? „Filmvilág” 2005, nr 6, http://filmvilag.hu/xereses_ frame.php?cikk_id=8271 (9.04.2013). 
dotyczy przedstawiciela grupy dominującej, potwierdza on tylko jej „naturalne” zróżnicowanie, niemożność uogólnienia. W zachodnim dyskursie skorumpowany biały polityk nigdy nie będzie postrzegany jako ktoś przynoszący hańbę całej rasie. Natomiast wszelkie negatywne zachowania reprezentanta świata uciśnionego są natychmiast generalizowane jako typowe. Wynika to $\mathrm{z}$ domniemania o homogeniczności wspólnoty kolonizowanych, pozbawionej tego co wyjątkowe i osobli$w^{15}$. Stereotyp rumunskiego-węgierskiego troglodyty $w$ omawianych filmach, firmowany wielokrotnie twarzą tego samego aktora, sugeruje reprezentatywność ze wzmocnioną siłą.

Krytycy zwykle odnajdują w mrocznych rumuńsko-węgierskich historiach uniwersalne przesłanie ${ }^{16}$. Problem polega jednak na tym, że owe mityczne opowieści, umiejscowione na pierwszy rzut oka w uniwersalnej naturze, „sferze poza kulturą", dają się de facto zlokalizować w konkretnym obszarze geograficznym. Wyjątkowa mieszanka języków węgierskiego i rumuńskiego czy specyficzne lokalne dialekty, jakimi posługują się bohaterowie, w większości przypadków nie pozostawiają wątpliwości. Siedmiogrodzka badaczka Mona Dánél bez trudu dostrzegła też $\mathrm{w}$ omawianych filmach szereg innych, mniej lub bardziej subtelnych znaków topograficznych, umożliwiających orientację w terenie. Przykładem może być długo eksponowany w Delcie napis na statku - skrót nazwy państwa, ROU czy muzyka ze ścieżki dźwiękowej wspomnianego filmu Wernera Herzoga Nosferatu - utwór On the way zespołu Popol Vuh, odsyłający do toposu rumuńskiego Drakuli. Celem podróży tytułowej bohaterki Katalin Vargi jest nieistniejąca w rzeczywistości miejscowość Jádszereda, której nazwa brzmi jednak bardzo rumuńsko. Jej pierwszy człon „iad” oznacza w tym języku "piekło”, a drugi występuje w nazwach wielu innych autentycznych rumunskich miejscowości (Csíkszereda, Nyárádszereda). Efekt organicznego wpisania uniwersalnych, bezosobowych historii w określony region jest taki, doszła do wniosku Dánél, że „morderstwo, kazirodztwo, samosąd jawią się od tej pory jako (uniwersalna) natura danej kultury"17.

15 Zob. E. Shochat, R. Stam, op. cit. New York 1997, s. 183.

${ }^{16}$ Na przykład Gábor Gelencsér stwierdził, że obsypana nagrodami Delta (nagroda za reżyserię, za muzykę i nagroda krytyków na Festiwalu Filmów Węgierskich w 2008 r.; nagroda FIPRESCI w Cannes w 2008 r.) wpisuje się w najznakomitszy trend w kinie węgierskim minionej dekady - tzw. czarną serię, której autorzy (w tym Béla Tarr) wychodząc od materialnej, namacalnej rzeczywistości, wznoszą się na filozoficzny poziom uniwersalnych, ponadczasowych pytań dotyczących ludzkiego bytu. Gelencsér zinterpretował Deltę jako mityczną wizję, wariację na temat ciągle powracający w twórczości Mundruczó - opowieść o tym, jak dominujące środowisko społeczne piętnuje i unicestwia irracjonalny, dziki, ale głęboko ludzki świat instynktów i namiętności, jak miażdży postawy uznane w jego kręgach za dewiacje. Zob. G. Gelencsér, De övéi nem fogadták be.... „Filmvilág” 2008, nr 9, http:// filmvilag.hu/xereses_frame.php?cikk_id=9471 (9.04.2013).

17 M. Dánél, op. cit., s. 59-60. 


\section{WĘGIERSKI KONKWISTADOR}

Skolonizowana kultura wielonarodowościowej Rumunii bywała odróżniana od kultury kolonizującej poprzez kontrast z wizerunkiem węgierskiego przybysza. Schemat fabularny Delty i Dallas... oparty jest na motywie powrotu męskiego bohatera do rodzinnego domu $\mathrm{w}$ Rumunii, na ziemię ojczystą. Historia opowiedziana w obu filmach rozpoczyna się $\mathrm{w}$ chwili, gdy od dawna nieobecni synowie przyjeżdżają, aby zająć miejsce brakującego bądź zmarłego ojca, na nowo posiąść utraconą ziemię i kobietę. W owych męskich powrotach, próbach odzyskania "swojego", "zostawionego", realizuje się wariant międzywojennego myślenia, uzasadniającego poczucie wyższości i prawo do ziemi pierwotnym jej posiadaniem. Filmowi przybysze - Węgrzy spoza rumuńskiej prowincji - od początku stają się właścicielami spojrzenia - to z ich perspektywy oglądamy świat, w który wchodzą jako reprezentanci cywilizacji wyższego rzędu.

Już na pierwszy rzut oka istotnie różnią się wyglądem od miejscowych, szczególnie bohater Dallas, Radu, który w białej koszuli wysiada na wysypisku śmieci z białej Daci. Mihail podróżujący do Delty Dunaju statkiem, wkracza do akcji z pozycji białego odkrywcy dziewiczych terenów, dzięki sposobowi filmowania podróży, typowemu w klasycznych filmach kolonialnych ${ }^{18}$. Ulokowana na statku kamera z perspektywy protagonisty, mknie w kierunku naturalnego krajobrazu, skąpanego w czerwonym świetle wschodzącego słońca. Wystarczyłoby ustawić ją na lądzie, z punktu widzenia tubylców, aby nadać „odkrywcy” status „intruza”.

Bohaterowie obu filmów uosabiają wartości zachodniej cywilizacji - kulturę, wiedzę, prawo i porządek. Radu, z zawodu nauczyciel, okazuje się jedynym piśmiennym człowiekiem $\mathrm{w}$ wiosce, po tym, jak zmarł jego ojciec - ostatni wykształcony. Wypełnia go entuzjastyczne poczucie misji - uczy małego chłopca czytać, chce stworzyć w osadzie szkołę. Stojąc na straży sprawiedliwości, przeciwstawia się mafii dręczącej miejscowych i wybawia ich w przemyślny sposób, nie zniżając się do poziomu przemocy ${ }^{19}$. Mihail z Delty buduje dom na wodzie, demonstrując tym swą władzę nad naturą. Występuje też w roli swoistego Zbawiciela. Jego postać otacza $\mathrm{w}$ filmie złożona sieć biblijnych odniesieńn ${ }^{20}$, z których kluczowym wydaje się skojarzenie z Jezusem. Bierze udział w cudownym połowie - rozmnożeniu ryb i „ostatniej wieczerzy”, podczas której dzieli chleb i (zastępującą wino) palinkę.

${ }^{18}$ Zob. E. Shochat, of Empire: Toward a Feminist Ethnography of the Cinema. W: R. Stam, T. Miller (red.), Film and Theory. An Anthology. Oxford 2000, s. 673-674.

${ }^{19}$ L. Kolozsi dostrzegł w konstrukcji bohatera pokrewieństwo z postaciami z westernów. Zob. A szemétdomb. „Filmvilág” 2005, nr 4, http://filmvilag.hu/xereses_frame.php?cikk_id=8199 (data dostępu: 9.04.2013).

20 Więcej pisał o tym G. Gelencsér, op. cit. 
Obaj bohaterowie przybywają do rumuńskich miejscowości, oferując zbawienie, ale ich misja kończy się fiaskiem. Zostają niewdzięcznie odrzuceni przez "swoich". Radu ostatecznie wyjeżdża z romskiego Dallas, bo zabijają mu ukochaną. Mihail, żyjący w zakazanym związku z siostrą w Delcie, przypłaca powrót do domu własnym życiem. Gelencsér słusznie dostrzegł w filmie Mundruczó ilustrację fragmentu z Prologu biblijnej Ewangelii według św. Jana. Fragment ten dobrze podsumowuje też przesłanie Dallas. Dotyczy Słowa, które „było na świecie, przez Nie stał się świat, a jednak świat Go nie poznał. Przyszło do swojej własności, lecz swoi go nie przyjęli" $(1,10-1,11)$.

\section{CIAŁA SKOLONIZOWANE}

Perspektywa widzenia $\mathrm{w}$ omawianych filmach węgierskich, przynależna męskiemu hegemonowi, ukształtowała specyficzny, skolonizowany wizerunek kobiety. Shochat w tekście Gender and Culture of Empire (1991) dokonała syntezy krytyki feministycznej i postkolonialnej dla potrzeb badań filmowych, dowodząc kluczowej roli metafor związanych z płcią w kulturze imperium ${ }^{21}$. Myślenie o podbitych terytoriach w kategoriach "dziewiczego krajobrazu”, "dziewiczej ziemi” (taka jest chociażby etymologia nazwy amerykańskiego stanu Virginia), maskowało prawdę o wywłaszczeniu jej mieszkańców i podtrzymywało iluzję niesienia „misji cywilizacyjnej”. „Ziemia wydająca plony - pisała Shochat, rodząca dla jej rdzennych mieszkańców, a więc »matka«, jest metaforycznie przedstawiana jako dziewica, »nietknięta natura«, czyli jako dostępna i oczekująca pana"22. Dobitnym wizualnym odwzorowaniem tego konstruktu myślowego jest XVI-wieczny obraz flamandzkiego malarza Jana van der Straeta, przedstawiający wyjście na ląd Amerigo Vespucciego w Ameryce (1589). Zdobywcę, uzbrojonego w atrybut krzyża, zbroi i kompasu, wita rdzenna Amerykanka - naga kobieta, będąca harmonijnym przedłużeniem przyrody za jej plecami ${ }^{23}$.

We współczesnych węgierskich filmach o Rumunii, tak jak w klasycznym kolonializmie, można dostrzec symboliczny znak równości pomiędzy ziemią, przyrodą a kobietą. Najbardziej bezpośrednio wyraża się to w imieniu bohaterki Delty - Fauna. Istotna różnica wynika jednak z tego, że figury kobiece stanowią projekcję wyobrażeń nietypowego, bo węgierskiego konkwistadora - wyobrażeń o ziemi podległej mu ponad tysiąc lat, a potem nagle odebranej przez Innego. Figury kobiece skrywają resentyment i rekompensują niemoc ${ }^{24}$.

${ }^{21}$ Zob. E. Shochat, op. cit., s. 669.

22 Ibidem, s. 670-671.

23 Zob. E. Shochat, op. cit., s. 670-671.

${ }^{24} \mathrm{~J}$. É. Havas doszła do wniosku, że w całym współczesnym węgierskim kinie autorskim postaci kobiece pełnią bardziej ograniczoną, instrumentalną rolę, niż w latach 60.-70. Ich ciała są zwykle 
Bohaterki omawianych filmów nie mają nic wspólnego z domeną „dziewiczej czystości". Jawią się jako ciała uprowadzone, zajęte gwałtem. W każdym z pięciu utworów pojawia się scena lub motyw zgwałcenia. Niekiedy nawet bez żadnego umocowania dramaturgicznego, jedynie w celach "kompozycyjnych” (Delta) ${ }^{25}$; a nawet za cenę spójności kompozycyjnej (Podróż Iszki) ${ }^{26}$. Kobiety nie żyją ze swoimi mężami, tylko ze zwyrodniałymi kochankami (matka Fauny i Mihaila w Delcie). Rodzą „obce” dzieci - owoce gwałtu (Katalin Varga) albo jednorazowej przygody (Mona z Bibliotheque Pascal). Są niesprawiedliwie obrzucane niedwuznacznymi obelgami w najbardziej eksponowanych momentach. Katalin Varga rozpoczyna się od słów jej męża: „Cała wieś będzie mnie uważać za męża kurwy, ladacznicy!", a Fauna z Delty wielokrotnie słyszy przed śmiercią z ust napastników: „Powiedz, że jesteś kurwą!". Te, którym faktycznie przyszło się prostytuować, robią to bo zostały porwane przez handlarzy żywym towarem (Iszka i jej koleżanki, Mona z Bibliotheque).

Pewnego wyłomu w tym schemacie dokonał Sz. Hajdu w Bibliotheque Pascal. Główna bohaterka, Mona, zostaje sprzedana na Zachód przez własnego ojca. Jej gwałcicielami nie są prymitywni mieszkańcy rumuńskiej prowincji, lecz bywalcy Biblioteki Pascala - wyjątkowo perwersyjnego domu publicznego dla intelektualnej śmietanki Londynu. "Cywilizowani” użytkownicy wysokiej literatury przychodzą do Mony przebranej za Joannę d'Arc lub Desdemonę i rozpoczynają brutalne spotkanie od rytualnego wygłoszenia cytatu z odpowiedniego dzieła sztuki. Hajdu jako jedyny zdobył się na zawoalowaną autorefleksję dotyczącą węgierskiej (auto)kolonizacji. Zwrócił uwagę, że Węgrzy sprzedają kobietę zachodniemu spojrzeniu - uprawiają "dyskurs zachodni”, zmierzający do supremacji, pozbawiający swój przedmiot tego, co wyjątkowe i osobliwe, narzucający mu zaprojektowaną przez siebie (archetypiczną) tożsamość ${ }^{27}$.

zredukowane do podstawowego znaczenia, utrwalonego przez filmy Jancsó - symbolizują zdanie na cudzą łaskę, upokorzenie. Zob. Test-tanok. Kortárs magyar szerzői filmek nóképe. „Metropolisz” 2011, nr 3.

${ }^{25}$ G. Gelencsér tak tłumaczył obecność tej sceny w filmie: „sekwencja zgwałcenia, jedyna sfilmowana $\mathrm{w}$ dalekim planie, nie ma następstw dramaturgicznych (dziewczyna nie $\mathrm{z}$ tego powodu opuszcza matkę i ojczyma), lecz „kompozycyjne” jako powtórzenie. Kiedy dziewczyna rozchorowuje się po tym, co zaszło, chłopak znów musi kogoś pielęgnować, tak jak robił to w jedynym ujawnionym epizodzie z przeszłego życia" (G. Gelencsér, op. cit.).

${ }^{26}$ Zakończenie filmu Podróż Iszki - sceny na statku, gdzie dochodzi do brutalnego gwałtu jednej z dziewcząt i nie ma już raczej wątpliwości, jak potoczą się losy głównej bohaterki, nie pasuje do całości filmu, naśladującego powściągliwy styl dokumentalny. Na wyraźne pęknięcie w kompozycji wskazywali też krytycy. Zob. K. Muhi, Épphogy csak érintsd! „Filmvilág” 2007, nr 11, http:/ / www.filmvilag. hu/xista_frame.php?cikk_id=9172 (data dostępu: 10.04.2013).

$27 \mathrm{~W}$ charakterystyczny sposób Mona, zagadnięta na początku filmu o pochodzenie, tłumaczy, że jest Węgierko-Rumunką. W Bibliotece Pascala traci istotny element swej tożsamości - przymuszana do odpowiedzi przez stręczyciela, przytakuje, że jest Rumunką. 
Węgierski (auto)kolonializm, uwidoczniony $\mathrm{w}$ omawianych filmach, polegający na kolonizowaniu Węgrów „peryferyjnych" przez Węgrów „centralnych”, na narzucaniu im tożsamości „Dzikiego Wschodu Europy Wschodniej”, jest sposobem na rozpamiętywanie utraconej władzy i jej symboliczne utwierdzanie w zbiorowej pamięci - jak wynika z Biblioteki Pascala - sposobem wyjątkowo perwersyjnym, a także zgubnym. Paradoksalnie, odzieranie z niepowtarzalności, sprowadzanie Rumunii i jej węgierskich mieszkańców do sprawdzonych szablonów, skazuje na niebyt nie tylko wieloetniczne bogactwo owych terenów, ale też tysiącletnie dziedzictwo kulturalne Węgrów, pozostawione za wschodnią granicą. Z obrazu Rumunii, utrwalonego we współczesnych filmach węgierskich, wyziera mentalna spuścizna Trianon, na którą w dosadny sposób wskazał węgierski pisarz z Siedmiogrodu, Ádám Bodor:

Prawdziwym przekleństwem tego fatalnego wydarzenia okazała się jednak nie utrata dawnych terytoriów - $\mathrm{w}$ istocie już od dość dawna przeważali tam liczebnie przedstawiciele innych narodowości, a my nie wykazywaliśmy należytej troski o te tereny - lecz fakt, że wraz z utratą prowincji nasza ojczyzna sama stała się prowincją, i to w najczystszym tego słowa znaczeniu. Nasze myślenie uwięzło w diabelskim kręgu, z którego po dziś dzień nie łatwo nam się wyrwać, w dodatku dramatyczny obraz naszego okrojonego kraju napawa nas jakąś głupią, popychającą do pogardy dla innych dumą, za sprawą której siedmiogrodzkiego Węgra uważa się dziś za obywatela drugiej kategorii już nie tylko $\mathrm{w}$ jego ojczystej ziemi, gdzie został zepchnięty do rangi przedstawiciela mniejszości, ale uważa się go za gorszego Węgra także na samych Węgrzech. Bezsprzecznie mamy tu do czynienia z jakimś szczególnym rodzajem głupoty, która stała się dziś ważnym, jeśli nie decydującym, elementem naszej tożsamości ${ }^{28}$.

28 Á. Bodor, Zapach więzienia. Odpowiedzi na pytania Zsófii Balla. Przeł. M. Komorowska-Fotek. Wołowiec 2004, s. 27. 
